\title{
The Effect of COVID-19 Pandemic on the Hip Fractures in Advanced Age
}

\author{
Kovid-19 Pandemisinin IIleri Yaş Kalça Kırıklarına Etkisi
}

\author{
Ahmet Metin Özsezen $\odot$, Ahmet Burak Bilekliø, Anıl Özgür $\odot$, Onur Denizhan Sivri®, \\ Çăgrı Neyişci $\odot$, Yusuf Erdem ${ }^{\oplus}$
}

Cite as: Özsezen AM, Bilekli AB, Özgür A, Sivri OD. Neyişci Ç, Erdem Y. The Effect of COVID-19 pandemic on the hip fractures in advanced age. Forbes J Med. 2021;2(2):74-8.

\section{ABSTRACT}

Objective: Hip fractures due to domestic low-energy traumas are common problems that can cause significant morbidity and mortality in the elderly population. Since the Covid-19 outbreak, although the lock-down of older people could decrease contagion, the incidence of domestic traumas did not decrease, and led to development of various comorbidities. In this study, we aimed to compare the epidemiology of hip fractures in 6 months of the pandemic in 2020, with the equivalent 6-month period in the previous year to determine the relationship between lock-down and hip fractures due to domestic falls.

Method: In this retrospective study, patients over 65 years old who were hospitalized due to hip fractures between May 1st, 2020 - November 30th, 2020 were compared with the similar cohort hospitalized between May 1st, 2019 - November 30th, 2019. The patients were compared in terms of demographic characteristics, American Society of Anesthesiologists (ASA) scores, type of anesthesia, time until surgery, comorbidities, surgical treatment modality, need for postoperative primary care unit, postoperative complications, and mortality.

Results: Overall, 210 patients were included in our study. There was no significant difference between the groups regarding demographic characteristics and ASA scores. In the 2020 group, there were eight patients (8.6\%) who were Covid-19 PCR- positive. There was no death proven by PCR that was related to COVID-19 disease . Time to surgery, fracture type, anesthesia type did not differ between the two groups. The need for a postoperative primary care unit was higher in the 2020 group. Ninety-day mortality rates were not significantly different between the two groups.

Conclusions: In conclusion, despite higher mortality rates described in the literature, there was no Covid -19 associated mortality in our study. Hip fractures in the elderly did not alter with social mobilization; hence they usually occur due to domestic low- energy traumas. Reporting of the information in this patient group by all centers will provide important data in the management of hip fractures in this special process.

Keywords: Covid-19, hip fractures, pandemics, osteoporotic fractures

\section{öz}

Amaç: Ev içi düşük enerjli travmalar sonrası gelişen kalça kırıkları, yaşlı popülasyonda önemli bir morbidite ve mortalite sebebidir. Kovid-19 pandemisinde ileri yașlı insanların sokağa çıkma kısıtlamaları ile bulașıcılık azalsa da, ev içinde yaşanan travmalar azalmamakta ve farklı morbiditelere de yol açmaktadır. Bu çalışmada, pandemi sürecinde gelişen ev içi düşmelere bağlı kalça kırıklarının epidemiyolojik verilerini 2019 yılının aynı zaman aralığında gelişen kırık verileri ile karşılaştırmayı amaçladık.

Yöntem: Retrospektif olarak planlanan çalışmamızda, 1 Mayıs 2020 - 30 Kasım 2020 tarihleri arasında kalça kırığı nedeniyle hastaneye yatırılan 65 yaş üstü hastalar, 1 Mayıs 2019 - 30 Kasım 2019 arasındaki benzer kohort ile karşılaştırıldı. Hastalar demografik özellikleri, American Society of Anesthesiologists (ASA) sınıflandırma skorları, anestezi tipi, cerrahiye kadar geçen süre, komorbiditeler, cerrahi tedavi yöntemi, postoperatif yoğun bakım ihtiyacı, postoperatif komplikasyonlar ve mortalite açısından karșılaştırıldı.

Bulgular: Çalışmamıza toplam 210 hasta dahil edildi. Demografik özellikler ve ASA puanları açısından gruplar arasında anlamlı bir fark yoktu. 2020 grubunda Kovid-19 PCR pozitif olan sekiz hasta (\% 8.6) vardı. PCR ile kanıtlanmış Kovid-19'a bağlı bir ölüm saptanmadı. Ameliyathaneye girme süresi, kırık tipi, anestezi tipi iki grup arasında farklılık göstermedi. Komorbidite oranları 2019 grubunda pulmoner ve kardiyovasküler alanda anlamlı olarak yüksekti. Postoperatif yoğun bakım ihtiyacı 2020 grubunda daha yüksek saptandı. 90 günlük mortalite açısından iki grup arasında anlamlı fark saptanmadı.

Sonuc: Sonuç olarak, literatürde tanımlanan yüksek mortalite oranlarına rağmen çalışmamızda Kovid-19 ile bağlantılı bir mortalite görülmemiştir. Kalça kırıkları ev içi düşük enerjili travmalar ile geliştiği için sosyal mobilizasyonda yaşanan değişikler ile sıklıklarının değişmediği saptanmıştır. Bu hasta grubundaki bilgilerin tüm merkezlerce raporlanması yaşanan bu özel süreçte kalça kırıklarının yönetiminde önemli bilgiler sağlayacaktır.
Received/Geliş: 02.02.2021

Accepted/Kabul: 22.06.2021

Publication online: 13.08 .2021

Sorumlu Yazar/

Corresponding Author: Ahmet Metin Özsezen

University of Health Sciences Gülhane Faculty of Medicine Orthopedics and Traumatology Department metinozs@yahoo.com

ORCID: 0000-0002-2298-021X

A.B. Bilekli 0000-0002-6294-4838 C. Neyișci 0000-0001-8481-7808

Gülhane Research and Training Hospital Orthopedics and

Traumatology Department

A. Özgür 0000-0002-5877-0628

O.D. Sivri 0000-0003-3728-2112

Y. Erdem 0000-0002-8685-2356

University of Health Sciences Gülhane Faculty of Medicine Orthopedics and Traumatology Department

Anahtar kelimeler: Kovid-19, kalça kırığı, pandemi, osteoporotik kırıklar 


\section{INTRODUCTION}

COVID-19 outbreak started in December 2019 and spread out all around the world within months. According to the World Health Organization database, there have been over 75 million cases and over 2 million deaths since the start of the pandemic. ${ }^{1}$ In Turkey, by January 15th, 2021, there have been 2.373.115 confirmed cases of COVID-19 with 19.115 deaths since the pandemic has started ${ }^{2}$. The risk of mortality increases with older age and pre-existing health conditions. ${ }^{3,4}$

Hip fractures due to domestic low-energy traumas are common problems that can cause significant morbidity and mortality in the elderly population. The incidence of hip fractures has increased over the last decades due to the aging population. ${ }^{5}$ Studies have shown that $86 \%$ of hip fractures occur in individuals aged 65 and older. ${ }^{5}$ Shortterm mortality occurring within the first six months constituted $56 \%$ of the deaths related to hip fractures. ${ }^{\circ}$

As determined by the latest data, this outbreak has higher mortality and morbidity among older people. Due to the higher comorbidities, there have been numerous studies progressed by different disciplines of medicine. Although the lock-down of older people could decrease contagion, indoor situations could also increase different types of comorbidities. In this study, we aimed to compare the epidemiology of hip fractures in 7 months of the pandemic in 2020, with the equivalent 7-month period in the previous year to determine the relationship between lock-down and hip fractures due to domestic falls.

\section{MATERIAL AND METHOD}

After ethics committee approval, patients over 65 years old who were hospitalized in The University of Medical Sciences Gulhane Faculty of Medicine Orthopedics Department due to hip fractures, between May $1^{\text {st }}, 2020$ - November 30th, 2020 (Referred as group A), and between May 1st, 2019 - November 30th, 2019 (Referred as group B) were included in this retrospective study.

The femoral head, neck, intertrochanteric and subtrochanteric fractures were analyzed, whereas hip fractures and pathological fractures, gunshot wounds, and periprosthetic fractures, were excluded from the study. We also excluded patients who refused to undergo surgical treatment.

Patients were compared in terms of demographic characteristics, American Society of Anesthesiologists (ASA) classification scores, type of anesthesia, time to enter the operating room (OR), comorbidities, surgical treatment modality, need for postoperative primary care unit, postoperative complications, and mortality. COVID-19 infection rates and pulmonary complications were also recorded for the patients of 2020.

Statistical analyses were performed using IBM SPSS version 25.0 software (IBM SPSS Statistics for Windows, Version 22.0. Armonk, NY, USA). The variables were investigated using visual (histograms, probability plots) and analytical methods (Kolmogorov-Simirnov/Shapiro-Wilk test) to determine whether they were normally distributed or not. Descriptive analyses were presented using mean and standard deviations for normally distributed variables and medians and interquartile range (IQR) for the non-normally distributed variables. Median scores for groups were compared with the nonparametric MannWhitney U test. Student's t-test was used for comparing parametric variables between groups. Chi-square test was used to compare proportions in different groups. A p-value of less than 0.05 was considered statistically significant.

\section{RESULTS}

Overall, 210 patients were detected from our database. Seven patients who refused to undergo surgical treatment or transferred to another institution by their own will, and six patients with missing data were excluded from the study. The data collection chart is presented in Figure 1. 


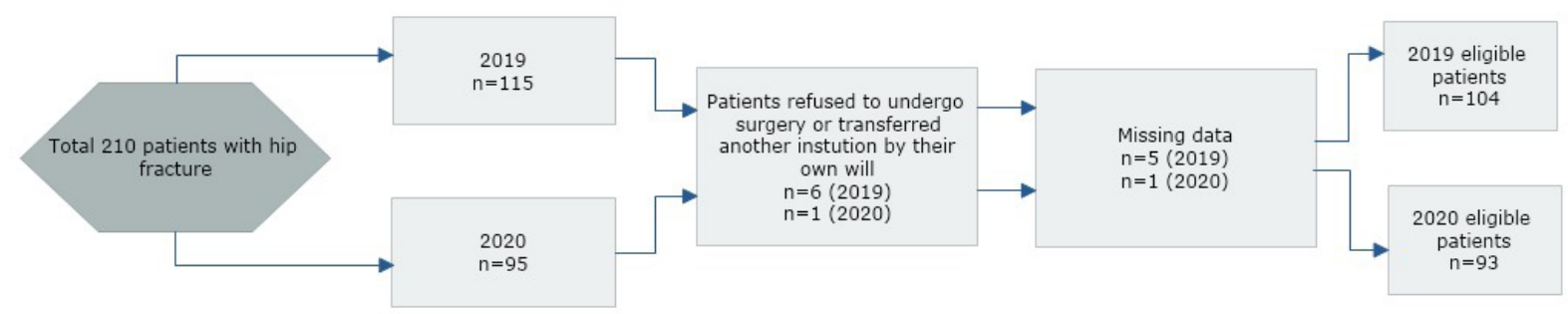

Figure 1: Patient selection and eligibility algorithm

Table 1. The demographic characteristics of patients with hip fractures.

\begin{tabular}{llll}
\hline & $\begin{array}{l}\text { Group A } \\
(2020)\end{array}$ & Group B & (2019) \\
\hline Gender male/female & $33 / 60$ & $34 / 70$ & 0.6 \\
Age,median (IQR) & $81.7(79.0-87.0)$ & $81.5(77.0-87.5)$ & 0.9 \\
ASA n (\%) & & & 0.3 \\
2 & $33(35.5)$ & $32(30.8)$ & \\
3 & $48(51.6)$ & $55(52.8)$ & \\
4 & $10(10.8)$ & $16(15.4)$ & \\
5 & $2(2.1)$ & $1(1)$ & \\
\hline
\end{tabular}

There was no significant difference between the groups regarding demographic characteristics and ASA scores (Table 1).

In Group A, after June 2020, the COVID-19 polymerase chain reaction (PCR) test was routinely ordered for the patients before operation, and eight patients $(8.6 \%)$ were PCR-positive. Since results of PCR tests were obtained within 24 hours, they did not alter the preoperative preparation time. PCRpositive patients were transferred to COVID-19 department and operated after negative PCR results were obtained. There was no death proven by PCR that was related to COVID-19 disease. Time to surgery, types of fractures, and anesthesia perfomed did not differ between the two groups. Comorbidity rates were significantly higher in the 2019 group (0.03), mostly in terms of the pulmonary and cardiovascular comorbidities. The need for a postoperative primary care unit was higher in the 2020 group. Ninety-day mortality, which was our primary outcome, was not significantly different between the two groups (Table 2).

\section{DISCUSSION}

This study investigated how the COVID-19 pandemic affects the mortality rates and perioperative parameters in hip fractures associated with high morbidity and mortality in the elderly patient group. Lock-down has been implemented for the people who were over 65 years, most of 2020 in our country. Although most hip fractures occur in-home, patient demographics did not alter despite the lockdown in our study. The number of COVID-19 positive patients was very low, so we think that the morbidity directly caused by COVID-19 has little reflection on the overall results.

The study by Vives et al. ${ }^{7}$, LeBrun et al. ${ }^{8}$, Egol et al. ${ }^{9}$ and Cheung et al. (10) found that time to surgery were $2.4,1.5,1.25$ and 2 days, respectively. In our study, the time to surgery in 2020 was longer than these studies and 2019 results in our center. In 2020, longer time intervals were thought to be related to the anesthesia team's tight schedule, as they mainly contributed to the treatment of severe COVID-19 patients in the intensive care unit. The occupancy rate in intensive care units contributed to the delay because patients with hip fractures who had higher ASA scores might need intensive care after the surgery. After June $1^{\text {st }} 2020$, we started to obtain COVID-19 PCR samples routinely from hospitalized patients. If results were positive, we transferred these patients 
Table 2. Results of patients with hip fractures in Groups A (2020) and B (2019).

\begin{tabular}{|c|c|c|c|}
\hline & $\begin{array}{l}\text { Group A } \\
n=93\end{array}$ & $\begin{array}{l}\text { Group B } \\
\mathrm{n}=104\end{array}$ & P-value \\
\hline COVID-19 (+) & 8 & 0 & $0.01^{++}$ \\
\hline Time to enter the OR, days mean (SD) & $3(2-4.5)$ & $2.6 \pm 1.7$ & $0.3^{+}$ \\
\hline$<2$ days $n(\%)$ & $33(35.5)$ & $45(43.3)$ & \\
\hline$>2$ days $\mathrm{n}(\%)$ & $60(64.5)$ & $59(56.7)$ & \\
\hline Fracture type (\%) & & & $0.3^{+}$ \\
\hline Femoral Neck & 35 (37.6) & $31(29.8)$ & \\
\hline Intertrochanteric & $49(52.7)$ & $66(63.5)$ & \\
\hline Subtrochanteric & $9(9.7)$ & $7(6.7)$ & \\
\hline Anesthesia type (\%) & & & $0.5^{+}$ \\
\hline Regional & 79 & 91 & \\
\hline General & 14 & 13 & \\
\hline Comorbidities present $\mathbf{n}(\%)$ & $83(89.2)$ & $101(97.1)$ & $0.03^{* *}$ \\
\hline Cardiovascular & $67(72)$ & $90(86.5)$ & $0.01^{* *}$ \\
\hline Respiratory & $14(15.1)$ & $32(30.8)$ & $0.01 * *$ \\
\hline Endocrine & $35(37.6)$ & $37(35.6)$ & 0.8 \\
\hline Urinary & $7(7.5)$ & $16(15.4)$ & 0.08 \\
\hline Gastrointestinal & $6(6.5)$ & $7(6.7)$ & 0.9 \\
\hline Neurologic-psychiatric & $31(33.3)$ & $46(44.2)$ & 0.1 \\
\hline Surgical treatment modality (\%) & & & $0.2^{+}$ \\
\hline Hemiarthroplasty & $33(35.4)$ & $29(27.8)$ & \\
\hline Proximal femoral nailing & $56(60.2)$ & $73(70.1)$ & \\
\hline Conservative & $1(1.1)$ & $1(1.0)$ & \\
\hline ORIF & $3(3.2)$ & $1(1.0)$ & \\
\hline Need for postoperative primary care unit (\%) & $21(22.6)$ & $9(8.7)$ & $0.007^{* *}$ \\
\hline 90-day Mortality, n (\%) & $16(17.4)$ & $19(18.3)$ & 0.9 \\
\hline
\end{tabular}

${ }^{*}$ Mann-Whitney-U, +Chi-Square test, ${ }^{++}$student t-test, ORIF: Open reduction internal fixation

to the COVID-19 department to treat the infection. We obtained a second PCR test at the end of the treatment and performed the surgeries, after the negative PCR results in compliance with COVID-19 protection rules against transmission of the virus. Although time to surgery were longer for the PCRpositive patients individually, there were no statistically significant differences between two groups. Although elective operations were canceled, the rate of trauma patients did not decrease as expected.

In patients who were treated conservatively, one patient in each group had inoperable end stage cancer. Conservative treatment approach was chosen for these patients, after shared decision making process conducted with their families.
In an international study published in Lancet ${ }^{11}$, higher mortality rates were reported for patients who underwent surgery with coexisting COVID-19 infection. In our study, none of the patients exited from COVID-19 disease. However, due to the limited number of COVID-19 positive patients in our cohort, our results cannot be generalized. In our study, anesthesia types did not differ between the two groups. In a study by Macey et al. ${ }^{12}$, regional anesthesia rates increased in 2020 from $33 \%$ to $65 \%$. In our study, regional anesthesia rates remained the same in two consecutive years because regional anesthesia is preferred for elderly hip fractures as a hospital policy due to lower complication rates than general anesthesia. 
The retrospective nature of our study is a limitation. Limited number of patients with COVID-19 infection hindered us from investigating the direct effect of COVID-19 on hip fractures. Patients who applied to the emergency department with hip fracture and coexisting COVID-19 infection might have been directly transferred to the COVID-19 department, so we could not reach the data of the deceased patients. This policy may have contributed to the low COVID-19 infection rate in our cohort. Finally, the interpretation of our findings may have been limited by the sample size.

In conclusion, despite the higher mortality rates described in the literature, there was no mortality in our study. Hip fractures in elderly patients did not alter with social mobilization; because they are usually domestic low- energy traumas. Hip fractures continue to be one of the leading and challenging issues of the orthopedic clinics during the pandemic period. All data related to this group of patients should be reported for a better understanding of the disease.

Ethics Committee Approval: Gülhane Scientific Research Ethics Committee (14.01.2021 / 202102)

\section{Conflict of Interest: None \\ Funding: None}

Informed Consent: Informed consent was not obtained from the patients as it was an epidemiological study.

\section{REFERENCES}

1. WHO. [COVID-19 Weekly Epidemiological Update World Health Organisation database]. 2020 Available from: https://covid19.who.int/.

2. General Coronavirus Information Table January [Republic of Turkey Ministry of Health]. 2020 [Available from: https://covid19.saglik.gov.tr/ TR-66935/genel-koronavirus-tablosu.html.
3. Jin J, Agarwala N, Kundu P, Harvey B, Zhang Y, Wallace E, et al. Individual and community-level risk for COVID-19 mortality in the United States. Nature Medicine. 2021;27(2):264-9. https://doi.org/10.1038/s41591-020-01191-8

4. Omori R, Matsuyama R, Nakata Y. The age distribution of mortality from novel coronavirus disease (COVID-19) suggests no large difference of susceptibility by age. Scientific Reports. 2020;10(1):1-9. https://doi.org/10.1038/s41598-020-73777-8

5. Congress U. Hip fracture outcomes in people age 50 and over. Background paper Government Printing Office, Washington, DC, USA. 1994.

6. Braithwaite RS, Col NF, Wong JB. Estimating hip fracture morbidity, mortality and costs. Journal of the American Geriatrics Society. 2003;51(3):364-70. https://doi.org/10.1046/j.1532-5415.2003.51110.x

7. Vives $J M M$, Jornet-Gibert $M$, Cámara-Cabrera J, Esteban PL, Brunet L, Delgado-Flores L, et al. Mortality rates of patients with proximal femoral fracture in a worldwide pandemic: preliminary results of the Spanish HIP-COVID observational study. The Journal of Bone and Joint Surgery American volume. 2020. https://doi.org/10.2139/ssrn.3576799

8. LeBrun DG, Konnaris MA, Ghahramani GC, Premkumar A, DeFrancesco CJ, Gruskay JA, et al. Hip fracture outcomes during the COVID-19 pandemic: early results from New York. Journal of Orthopaedic Trauma. 2020.

https://doi.org/10.1097/BOT.0000000000001849

9. Egol KA, Konda SR, Bird ML, Dedhia N, Landes EK, Ranson RA, et al. Increased mortality and major complications in hip fracture care during the COVID-19 pandemic: a New York City perspective. Journal of Orthopaedic Trauma. 2020. https://doi.org/10.1097/BOT.0000000000001845

10. Cheung ZB, Forsh DA. Early outcomes after hip fracture surgery in COVID-19 patients in New York City. Journal of Orthopaedics. 2020;21:291-6. https://doi.org/10.1016/j.jor.2020.06.003

11. Nepogodiev D, Bhangu A, Glasbey JC, Li E, Omar OM, Simoes JF, et al. Mortality and pulmonary complications in patients undergoing surgery with perioperative SARS-CoV-2 infection: an international cohort study. The Lancet. 2020;396(10243):27-38. https://doi.org/10.1016/S0140-6736(20)31182-X

12. Macey AR, Butler J, Martin SC, Tan TY, Leach WJ, Jamal B. 30-day outcomes in hip fracture patients during the COVID-19 pandemic compared to the preceding year. Bone \& Joint Open. 2020;1(7):4159 . https://doi.org/10.1302/2633-1462.17.BJO2020-0077.R1 